\title{
Approaches to the Installation of the Subsistence Level in the Context of the Food Security in Ukraine
}

\author{
Olena Shebanina ${ }^{1} \&$ Anna Burkovska ${ }^{1}$ \\ ${ }^{1}$ Department of Economic Cybernetics and Mathematical Modeling, Management Faculty, Mykolayiv National \\ Agrarian University, Ukraine \\ Correspondence: Anna Burkovska, Department of Economic Cybernetics and Mathematical Modeling, \\ Management Faculty, Mykolayiv National Agrarian University, Ukraine. E-mail: \\ anna.burkovskaya12@gmail.com, shebanina@mnau.edu.ua
}

Received: October 26, 2018; Accepted: November 7, 2018; Published: November 7, 2018

\begin{abstract}
The article highlights the problems of social security in Ukraine in the context of the food safety. The ratio of growth in rates of subsistence minimum and consumer prices is analyzed. The indicative subsistence level with the preservation of the purchasing power of the basic period is determined. The correlation-regression analysis of the impact of the subsistence minimum and budget expenditures on research and experimental development in the system of the agro-industrial complex on the level of economic availability of food products in Ukraine is conducted.
\end{abstract}

Keywords: subsistence level, food security, minimum wage, social standards, consumer price index, economic availability of food products, budget expenditures, correlation-regression analysis

\section{Introduction}

The regulation of relations in the field of standardization of social protection is carried out by many normative and legal acts. The most important among them are the Laws of Ukraine "On State Social Standards and State Social Guarantees", "On the Living Minimum", "On Social Services"; State Classifier of Social Standards, Decree of the Cabinet of Ministers "On Approval of Nutrition Sets, Nonfood Goods Sets and Services of Basic Social and Demographic Groups" (Krupa, 2013). State social standards and norms are aimed at the effective implementation of social policy, one of the main priorities of which is to ensure the food security in the country.

The European direction of the integration of Ukraine requires the obligatory maintenance of the level and quality of a social standards system based on the basic social standard of the subsistence minimum, guaranteed by the Constitution of Ukraine. The application of the social standards system makes it possible to regulate the living standards of the population, prevent a significant differentiation in income and reproduce the workers' ability to work (Bykova, Lobza \& Semenova, 2016). If the living wage is brought into line with the realities of the present, based on the structure and cost of consumption, then, firstly, it would significantly increase; and secondly, it would be a real indicator of living standards of the population; thirdly, it would be the goal which will ensure the social stability in the state (Nadtochii, 2012).

The establishment of the state minimum standards must be an important step in implementing the state budget policy. These standards have to determine the indicators of the volume and quality of the social services and guarantees provided to the public by the state. The qualitative system of the social standards, in particular, the subsistence minimum as the basis for determining the minimum wage and the provision of social assistance, will be possible in the case of a precise definition of the conceptual-categorical apparatus and scientifically-methodical substantiated approaches to the calculations of the consumer basket of subsistence minimum and other social guarantees (Trubina, 2016). This question is especially relevant for Ukraine, which tends to European integration, because its legislation on social policy must also correspond to European social values. Under such circumstances, the current system of state social standards and guarantees needs to be reviewed and adapted to modern living conditions (Novosilska, 2013).

The purpose of the article is to justify approaches to establishing living levels that would ensure at least a sustainable purchasing power of the population and take into account inflation factors in Ukraine and deflation of the national currency. 
The subject of the study is the processes in the national economy of Ukraine that influence the change in the real living costs and solvency of the population in the context of the food security.

\section{Literature Review}

Many scientists and researchers devoted their studies to solving the problems of ensuring the food security and social protection of the population. Thus, the study of ways to ensure consumer demand for food in terms of limited resources was researched by such scholars as Coleman M., Oehmke J., Weatherspoon D. and Weatherspoon L. (2015), and others. The ambiguity of the concept of food security and the lack of a well-defined methodology for its evaluation were the subject of the research of Altman M., Hart T. and Jacobs P. (2009) and others. The scientists noted that food security of individual households is determined not only by the volume of food production in the state, but by the systems of distribution and promotion of products.

Coleman-Jensen A., Gregory C. and Singh A. (2015) conducted a thorough study of households to assess the availability of food products for them. Scientists paid special attention to the nutritional behavior of the households that are under the poverty line and take part in the food support programmes. Darmon N. and Drewnowski A. (2008) established the relationship between the quality of the human diet and the level of their income, which has a corresponding effect on food security. Scientists researched some groups of products that are often included in food rations, depending on income level.

Hendrickson D., Smith C. and Eikenberry N. (2006) examined the availability of fruits and vegetables for lowincome households living in urban or rural areas. According to the focus of studied groups, scientists identified the main barriers to consumption. Liese A., Weis K., Pluto D., Smith E. and Lawson A. (2007) studied the availability of healthy and inexpensive food in rural areas for households. Scientists analyzed a set of stores that have different capacities to store products.

Monteiro C., Levy R., Claro R. and Castro I. (2011) investigated the impact of food intensive processing on the health of consumers. The scientists noted that the state should stop the substitution of food products with a minimum degree of treatment with intensively processed products containing substances which are harmful to humans. Morris J., Donkin A., Wonderling D., Wilkinson P. and Dowler E. (2000) reviewed the state standards of social security in terms of establishing a minimum income level for citizens. Scientists saw this issue as debatable and in need of an integrated approach, taking into account health and sanitation recommendations.

Morris J., Wilkinson P., Dangour A., Deeming C. and Fletcher A. (2007) in their studies justified the level of minimum income of the elderly people to ensure their biological and social needs at the basic level. Scientists proved that insufficiency of the subsistence minimum can be a barrier to the full-fledged life of the elderly people. Quinn K., Monroe B., Colaresi M., Crespin M. and Radev D. (2009) investigated the state regulation of social standards as a mechanism for ensuring food security in the state.

\section{Methodology}

The ratio between the rates of growth of the subsistence minimum and consumer prices was established in order to substantiate the establishing of living costs levels that would ensure the sustainable purchasing power of the population and to take into account inflation factors in the state and deflation of the national currency. On the basis of the average rising of consumer prices, the future value of the monetary amount of the subsistence minimum in 2017 is determined with the present value of 2010. The size of the subsistence minimum in 2010, expressed in USD, is used to establish the basis of purchasing power.

To determine the effect of the subsistence minimum and budget expenditures on research in the agro-industrial sector on the economic availability of foodstuffs, correlation-regression analysis was carried out, the model variables were identified, the parameters of the regression equation were found. The paired and multiple correlation coefficients allow us to establish a tight relation between the investigated factors. The usage of the determination coefficient gives an estimation of the statistical significance of the model.

\section{DiscussionofResults}

The establishment of a subsistence minimum that would ensure the purchasing power of the population should take into account the dynamics of consumer prices (Table 1) to support food security in the country.

These tables indicate an increase in the growth rates of consumer prices over the growth rates of the subsistence minimum in Ukraine for the studied period (from 2010 to 2017), which had a negative impact on the purchasing power of the population. In recent years (from 2014 to 2017), characterized by crises in the political and economic spheres, the consumer price growth over the rate of the subsistence minimum increasing is more than 2 times. 
Table 1. Dynamics of subsistence minimum and consumer prices in Ukraine in 2010-2017

\begin{tabular}{llll}
\hline \multirow{2}{*}{ Years } & \multicolumn{2}{l}{ Indexes } & \\
\cline { 2 - 4 } & $\begin{array}{l}\text { Cost of living, } \\
\text { UAH }\end{array}$ & $\begin{array}{l}\text { Rate of growth of the subsistence minimum } \\
\text { in relation to the previous year, } \%\end{array}$ & $\begin{array}{l}\text { Rate of growth of consumer prices in } \\
\text { relation to the previous year, } \%\end{array}$ \\
\hline 2010 & 849 & 21.1 & 9.4 \\
2011 & 923 & 8.7 & 8.0 \\
2012 & 1051 & 13.9 & 0.6 \\
2013 & 1142 & 8.7 & -0.3 \\
2014 & 1176 & 3.0 & 12.1 \\
2015 & 1253 & 6.5 & 48.7 \\
2016 & 1434 & 14.4 & 13.9 \\
2017 & 1623 & 13.2 & 14.4 \\
\hline Average value & $\mathrm{x}$ & 11.2 & 13.4 \\
$2010-2017$, p.p. & & & 22.3 \\
Average value & $\mathrm{x}$ & 9.3 & \\
$2014-2017$, p.p. & & &
\end{tabular}

Source: calculated using (Indeksy...) i (Prozhytkovyi...).

Taking into account the average consumer price growth rates, it is possible to calculate the indicative amount of the subsistence minimum in 2017, which would include full indexation of incomes, taking into account inflation trends, and would correspond to the purchasing power of the population in the base year (2010), based on the formula of future value of money:

$$
\mathrm{FV}=\mathrm{PV} *(1+\mathrm{r})^{\mathrm{n}}(1)
$$

where FV - future value of money;

$\mathrm{PV}$ - present value of money;

$\mathrm{r}$ - interest rate, $\%$.

$\mathrm{n}$ - multiplier increment.

Consequently, the indicative amount of the subsistence minimum in 2017, taking fully into account the existing inflation trends for the period from 2010 to 2017 , should be $849 *(1+0.134) 7=2047.38$ UAH. However, in addition to the significant impact of inflation on the purchasing power of the population in Ukraine, the instability of the political system, poor investment climate, negative balance of payments and other factors affect the UAH exchange rate. Thus, the last years of the period under the study were characterized by the significant deflation of the national currency, which led to the rise of the real purchasing power of the population. It made less accessible not only imported products, but also products manufactured on the domestic market, depending on the supply of raw materials or other factors of production from abroad. The dynamics of the change in the living costs in Ukraine in terms of USD is presented in Table. 2.

Table 2. Dynamics of the subsistence minimum in Ukraine in terms of USD

\begin{tabular}{cccc}
\hline Years & Cost of living, UAH & Rate USD/UAH (on 12/31) & Cost of living, USD \\
\hline 2010 & 849 & 7.94 & 106.9 \\
2011 & 923 & 7.9898 & 115.5 \\
2012 & 1051 & 7.993 & 131.5 \\
2013 & 1142 & 7.993 & 142.9 \\
2014 & 1176 & 15.7686 & 74.6 \\
2015 & 1253 & 24.0007 & 52.2 \\
2016 & 1434 & 27.1908 & 52.7 \\
2017 & 1623 & 28.0672 & 57.8 \\
\hline
\end{tabular}

Source: calculated using (Prozhytkovyi...) i (Arkhyv).

These tables show a tendency to the increasing of the living costs for Ukraine from 2010 to 2013; in 2014, there was a sharp decline in the nominal living costs, expressed USD (almost 2 times as compared to 2013), which is 
due to a significant devaluation of the UAH. In recent years the living costs expressed in USD shows a gradual increasing, but its level in 2017 is only $54 \%$ of 2010 and $40 \%$ of 2013 . Taking as a basis the level of solvency of the population, which was ensured by the living standard of 2010, in 2017 the nominal subsistence minimum should be $106.9 * 28.0672=3000.38 \mathrm{UAH}$. To maintain the solvency of the population at the 2013 level, the subsistence minimum in 2017 should be $142.9 * 28.0672=4010.8 \mathrm{UAH}$.

According to the current Decree of the Cabinet of Ministers of Ukraine №1379 "Some questions of food security" dated December 5, 2007, one of the main indicators of food security is the indicator of economic availability of products, which is defined as the share of aggregate food costs in aggregate total household expenditures (Postanova, 2007). According to the Decree, the 60\% level is considered as the limiting criterion for this indicator. At the same time, the subsistence level of the population has an inverse effect on this indicator, because the higher the solvency of citizens, the greater the number of consumable (food and non-food) and non-consumable costs they can carry, which, as a result, allows to reduce the share of food costs in the total costs. In addition, food security in the state is determined by the volume of budgetary expenditures for the development of the agroindustrial complex. We conducted a correlation-regression analysis, which determined the impact of these factors on the economic availability of food products, for this we identified the variables of the linear econometric model:

$\mathrm{Y}$ - vector of economic availability of food products (effective, dependent, endogenous variable); $\mathrm{X}_{1}$ - vector of subsistence minimum of Ukrainian population (factor, independent, exogenous variable); $\mathrm{X}_{2}$ - vector of budget expenditures for research and experimental development in the system of agro-industrial complex (factor, independent, exogenous variable); $\mathrm{U}$ - vector of residues (stochastic component).

Table 3. Output data for calculating the impact of factors on the economic availability of food products in Ukraine

\begin{tabular}{cccc}
\hline Years & $\begin{array}{c}\text { Economic availability of } \\
\text { food products, \% }\end{array}$ & $\begin{array}{c}\text { Cost of living, } \\
\text { UAH }\end{array}$ & $\begin{array}{c}\text { Budget expenditures for research and } \\
\text { experimental development in the system of } \\
\text { agro-industrial complex, mln UAH }\end{array}$ \\
\hline 2010 & 51.6 & 849 & 13.712 \\
2011 & 51.3 & 923 & 13.011 \\
2012 & 50.1 & 1051 & 136.512 \\
2013 & 50.1 & 1142 & 87.122 \\
2014 & 51.9 & 1176 & 63.088 \\
2015 & 53.1 & 1253 & 46.547 \\
2016 & 49.8 & 1434 & 50.511 \\
2017 & 47.9 & 1623 & 71.479 \\
\hline
\end{tabular}

Source: calculated using (Prozhytkovyi...), (Struktura...) i (Zakon...).

Substituting in the system of normal equations the calculated values obtained on the basis of the original data in Table 3, we obtained a system of normal equations in the following form:

$$
\left\{\begin{array}{c}
8 \beta_{0}+9451 \beta_{1}+482 \beta_{2}=405.8 \\
9451 \beta_{0}+11624965 \beta_{1}+587576.1 \beta_{2}=477751.2 \\
482 \beta_{0}+587576.1 \beta_{1}+40390.4 \beta_{2}=24264.3
\end{array}\right.
$$

Having solved this system of equations with respect to unknown estimates of the parameters $\beta_{0}, \beta_{1}$ and $\beta_{2}$, we obtained the following values of the system components: $\beta_{0}=55.1 ; \beta_{1}=-0.003 ; \beta_{2}=-0.011$.

Thus, the multiple regression equation, which characterizes the dependence of the level of economic availability of food products on the subsistence level of the population and budget expenditures on research and experimental development in the system of the agro-industrial complex of Ukraine, has the following form:

$\mathrm{Y}=55.1-0.003 \mathrm{x}_{1}-0.011 \mathrm{x}_{2}$.

The regression coefficients shows how much the level of economic availability of food products will change with the change of the corresponding factor per unit, assumed that the second factor is on an average level. Thus, if $\beta_{0}=55.1$ shows that in the absence of the influence of the investigated factors, the level of economic availability 
of the food products in Ukraine will be at an average level and will amount to $55.1 \%$, which corresponds to the normative requirements. At the same time $\beta_{1}=-0.003$ shows that the growth by the unit (by UAH 1) of the subsistence minimum of the population of Ukraine will lead to the decreasing of the share of expenditures on food products in the total costs of population by $0.003 \%$. Thus, to reduce the share of food costs in the total household expenses by $1 \%$ it is enough to increase the subsistence level by UAH 333.33 or by $20.5 \%$ from the current level (UAH 1623). At the same time, the growth of budget expenditures for research and experimental development in the system of agro-industrial complex by the unit (UAH 1 million) will lead to the decreasing in the share of food expenses in the total household costs by $0.011 \%$, since $\beta_{2}=-0.011$. Thus, it is enough to increase the budget expenditures for the research and experimental development in the agro-industrial complex by UAH 90.909 million or by $127.2 \%$ from the current level (UAH 71.5 million) in order to reduce the share of food costs in the total population expenditures by $1 \%$.

To determine the tightness of the relationship between the studied variables we should determine the correlation coefficients. The pair correlation coefficients will be equal to:

- between the level of economic availability of food products and the living costs of population $\left(\mathrm{r}_{\mathrm{yx} 1}=\right.$ 0.661). This coefficient shows the strong inverse relationship between variables. This means that the increasing in the subsistence minimum leads to the reduction in the share of food expenditures in the total population costs;

- between the level of economic availability of food products and budget expenditures on the research and experimental development in the system of agro-industrial complex $\left(\mathrm{r}_{\mathrm{yx} 2}=-0.421\right)$. This coefficient shows an inverse moderate relation between variables. This means that the increasing in budget costs on the research and experimental development in the agro-industrial complex leads to the reduction in the share of food costs in the total household expenditures;

- between the subsistence minimum of the population and the expenditures on the research and experimental development in the system of agro-industrial complex in Ukraine $\left(\mathrm{r}_{\mathrm{x} 1 \times 2}=0.309\right)$. This ratio shows a direct weak connection between the variables. This means that the increasing of one of the factors leads to the slight increasing of the second one.

The multiple coefficient of the correlation $\left(\mathrm{R}_{\mathrm{yx} 1 \times 2}=0.620\right)$ shows the strong correlation between the level of economic availability of food products in Ukraine and other factors included in the correlation model, such as the subsistence minimum and budget costs for the research and experimental development in the agro-industrial complex.

The multiple determination coefficient $\left(\mathrm{R}^{2}=0.384\right)$ shows that the $38.4 \%$ of variation of the level of economic availability of food products in the investigated period is due to the included factors. The remaining fluctuations in the level of economic availability of food products are due to other unintentional factors.

\section{Conclusions and Implications}

The subsistence minimum is used as a value of income sufficiency in order to ensure the normal functioning of the human body; it is an integral part of the mechanism of ensuring food security in the national economy of Ukraine. The subsistence minimum should ensure the purchasing power of the population at the level of purchasing the minimum set of food and non-food products needed to meet basic needs.

The establishment of a subsistence minimum in Ukraine that would ensure the purchasing power of the population should take into account the dynamics of consumer prices. The indicative amount of the subsistence minimum in 2017, which fully takes into account existing inflationary trends, should be UAH 2047.38.

In 2014, there was a sharp decline in the nominal living costs, expressed in USD (almost 2 times as compared to 2013), which is due to a significant devaluation of the UAH. In recent years the living costs expressed in USD shows a gradual growth, but its level in 2017 is only $54 \%$ of 2010 and $40 \%$ of 2013 . In 2017 the nominal subsistence minimum should be UAH 3000.38 , taking as a basis the level of solvency of the population, which was ensured by the living standard of 2010 .

The indicator of the economic availability of products is defined as the share of the aggregate food costs in the total household expenses and is one of the main indicators of the food security in Ukraine. Due to the absence of the investigated factors influence (changes in the subsistence level and budget expenditures for the research in the agrarian sector), the level of economic availability of food in Ukraine will be at an average level and will amount to $55.1 \%$, which meets regulatory requirements. 
The increasing by the unit (by UAH 1) of the living costs of the population in Ukraine will lead to the decreasing of the share of food expenses in the total costs of the population by $0.003 \%$. Thus, to reduce the share of food costs in the total household expenses by $1 \%$ it is enough to increase the subsistence minimum by UAH 333.33 or by $20.5 \%$ from the current level (UAH 1623). At the same time, the increasing in budget expenditures for research and experimental development in the system of agro-industrial complex by the unit (UAH 1 million) will lead to the decreasing of the share of expenditures on food products in the total household expenses by $0.011 \%$. Thus, it is enough to increase the budget expenditures for the research and experimental development in the agro-industrial complex by UAH 90.909 million or by $127.2 \%$ from the current level (UAH 71.5 million) in order to reduce the share of food expenditures in the total population expenditures by $1 \%$.

There is the strong correlation between the level of economic availability of food products in Ukraine and other factors included in the correlation model, such as the subsistence minimum and budget expenditures for the research and experimental development in the agro-industrial complex. The multiple determination coefficient $\left(\mathrm{R}^{2}=0.384\right)$ shows that the $38.4 \%$ of variation of the level of economic availability of food products in the investigated period is due to the included factors. The remaining fluctuations of the level of economic availability of food products are due to other unintentional factors.

\section{References}

Altman, M., Hart, T., \& Jacobs, P. (2009). Household food security status in South Africa. Agricultural Economics Research, 4, 345-361. https://doi.org/10.1080/03031853.2009.9523831

Arkhyv ofytsyalnoho kursa dolara SShA NBU [Electronic resource]. Retrieved from https://charts.finance.ua/ru/currency/official/-/1/usd

Bykova, A. L., Lobza, A. V., \& Semenova, L. Y. (2016). Prozhytkovyi minimum yak bazovyi sotsialnyi standart v Ukraini: Realii ta problemy vdoskonalennia. Naukovyi visnyk Mizhnarodnoho humanitarnoho universytetu. No 7, 108-114.

Coleman-Jensen, A., Gregory, C., \& Singh, A. (2015). Household food security in the United States in 2013. USDA-ERS Economic Research Report Number 173. http://dx.doi.org/10.2139/ssrn.2504067

Darmon, N., \& Drewnowski, A. (2008). Does social class predict diet quality? The American Journal of Clinical Nutrition, 5, 1107-1117. https://doi.org/10.1093/ajcn/87.5.1107

Hendrickson, D., Smith, C., \& Eikenberry, N. (2006). Fruit and vegetable access in four low-income food deserts communities in Minnesota. Agricultural and Human Values, 3, 371-383. https://doi.org/10.1007/s10460006-9002-8

Indeksy spozhyvchykh tsin na tovary $\mathrm{i}$ posluhy u 2002-2017 rr. [Electronic resource]. Retrieved fromhttp://www.ukrstat.gov.ua/

Krupa, V. R. (2013). Udoskonalennia teoretyko-metodolohichnykh pidkhodiv do vstanovlennia derzhavnykh sotsialnykh standartiv v Ukraini. Efektyvna Ekonomika, 12, 27-35.

Liese, A., Weis, K., Pluto, D., Smith, E., \& Lawson, A. (2007). Food store types, availability and cost of food in a rural environment. Elsevier, 11, 1916-1923. https://doi.org/10.1016/j.jada.2007.08.012

Maibutnia ta teperishnia vartist hroshei [Electronic resource]. Retrieved from http://studentbooks.com.ua/content/view/1308/42/1/2/

Monteiro, C., Levy, R., Claro, R., \& Castro, I. (2011). Increasing consumption of ultra-processed food and likely impact on human health: Evidence from Brazil. Public Health Nutrition, 1, 5-13. https://doi.org/10.1017/S1368980010003241

Morris, J., Donkin, A., Wonderling, D., Wilkinson, P., \& Dowler, E. (2000). A minimum income for healthy living. Epidemiology and Community Health, 12, 885-889. https://doi.org/10.1136/jech.54.12.885

Morris, J., Wilkinson, P., Dangour, A., Deeming, C., \& Fletcher, A. (2007). Defining a minimum income for healthy living (MIHL); older age, England. International Journal of Epidemiology, 6, 1300-1307. https://doi.org/10.1093/ije/dym129

Nadtochii, A. O. (2012). Napriamy vdoskonalennia metodyky rozrakhunku prozhytkovoho minimumu v suchasnykh umovakh rozvytku suspilstva. Teoriia Ta Praktyka Derzhavnoho Upravlinnia, 4(39), 231-241.

Novosilska, T. V. (2013). Prozhytkovyi minimum yak bazovyi derzhavnyi sotsialnyi standart. Visnyk SotsialnoEkonomichnykh Doslidzhen, 3(50), 175-181. 
Postanova KMU «Deiaki pytannia prodovolchoi bezpeky». (2007). [Electronic resource]. Retrieved fromhttp://zakon.rada.gov.ua/laws/show/1379-2007-\%D0\%BF

Prozhytkovyi minimum v Ukraini [Electronic resource]. Retrieved fromhttps://index.minfin.com.ua/ua/labour/wagemin/

Quinn, K., Monroe, B., Colaresi, M., Crespin, M. and Radev, D. (2009). How to analyze Political Attention with Minimal Assumption and Costs. American Journal of Political Science, 1. https://doi.org/10.1111/j.15405907.2009.00427.x

Struktura sukupnykh vytrat domohospodarstv [Electronic resource]. Retrieved fromhttp://www.ukrstat.gov.ua/

Trubina, M. V. (2016). Teoretychni ta normatyvni aspekty rozrakhunku prozhytkovoho minimumu v Ukraini. Porivnialno-Analitychne Pravo, 4, 127-130.

Weatherspoon, D., Oehmke, J., Coleman, M., \& Weatherspoon, L. (2015). Understanding consumer preferences for nutrition foods: Retailing strategies in a food desert. International Food and Agribusiness Management Review, 17, 61-82. Retrieved from https://www.ifama.org/resources/Documents/v17ia/WeatherspoonOehmke-Coleman.pdf

Zakon Ukrainy «Pro derzhavnyi biudzhet» [Electronic resource]. Retrieved fromhttp://zakon.rada.gov.ua/laws/show/2154-17

\section{Copyrights}

Copyright for this article is retained by the author(s), with first publication rights granted to the journal.

This is an open-access article distributed under the terms and conditions of the Creative Commons Attribution license (http://creativecommons.org/licenses/by/4.0/). 